\title{
KOMUNITAS GULMA PADA PERKEBUNAN KAKAO (Theobroma cacao) DI DATARAN TINGGI DESA DONGI-DONGI DAN DATARAN RENDAH DESA SIDERA
}

\author{
Yayang Istikana*, Wahyu Harso and Ramadhanil Pitopang \\ Jurusan Biologi, Fakultas Matematika dan IImu Pengetahuan Alam Universitas \\ Tadulako, Kampus Bumi Tadulako Tondo Palu, Sulawesi Tengah 94117
}

Corresponding author :yayang_istikana@yahoo.com

\begin{abstract}
Different elevation of lands can affect environmental conditions such as light intensity, temperature, and humidity. The environmental conditions will affect the growth and species of weeds. The aim of this study was to compare the diversity and species composition of weed comunities on highland and lowland of cacao plantation. The study was conducted by colecting the weed species from 25 plots with a size of $2 \times 2 \mathrm{~m}$. Every plot was placed by purposive sampling. The result showed that there were 26 species of weeds on highland while only 15 species of weeds were found on lowland. Weeds on highland was dominated by Ageratum conyzoides with important value index (IVI) of $62.07 \%$ while on lowland was dominated by Euphorbia hirta with IVI of $26.56 \%$. The weeds community has a medium diversity index while the value of Similarity Index (IS) was low (4.87\%) between weeds community on highland and lowland. It could be concluded that different environmental condition would affect the number and species of weeds.
\end{abstract}

Keywords : Weeds, Communities, Highlands, Lowlands

\section{PENDAHULUAN}

Kakao adalah tumbuhan yang tumbuh di bawah naungan hutan tropika, oleh karena itu, tidak tersedia banyak cahaya, dan kakao beradaptasi dengan mempunyai daun tipis yang relative lebar. Keterbatasan tersebut dioptimalkan dan menjadikan sosok kakao menjadi tumbuhan dengan perakaran dangkal. Keberadaan gulma yang biasanya terdiri dari rumput 
(Graminae), teki (Cyperaceae) atau herba lunak (Asteraceae) dan paku - pakuan (Pteridophyta) mempunyai sebaran akar sama seperti kakao, sehingga keberadaan gulma merepresentasikan ancaman berkurangnya ketersediaan sumberdaya alam untuk kehidupan kakao. Keberadaan gulma mengurangi porsi sumberdaya alam dan merugikan kehidupan kakao (Mahfudz, 2005).

Gulma merupakan tumbuhan yang mengganggu atau merugikan kepentingan manusia sehingga manusia berusaha untuk mengendalikannya Beberapa contoh jenis gulma adalah Imperata cylindrica (alangalang), Mimosa pudica (putri malu), Ageratum conyzoides (bandotan), Cyperus rotundus (rumput teki) (Sembodo, 2010).

Faktor iklim di dalamnya termasuk suhu udara, sinar matahari, kelembaban udara dan angin. Unsur - unsur ini sangat berpengaruh terhadap proses pertumbuhan tanaman. Ketinggian tempat mempengaruhi perubahan suhu udara. Semakin tinggi suatu tempat, misalnya pegunungan, semakin rendah suhu udaranya atau udaranya semakin dingin. Semakin rendah daerahnya maka semakin tinggi suhu udaranya atau udaranya semakin panas. Oleh karena itu ketinggian suatu tempat berpengaruh terhadap suatu wilayah. Perbedaan regional dalam topografi, geografi dan cuaca menyebabkan terjadinya perbedaan dalam tanaman, pola tanam, metode bercocok tanam dan situasi sosio-ekonomi. Pola tanam dari beberapa yang ditanam terus menerus serta keadaan iklim yang cocok akan meningkatkan dan kompleksnya serangan hama, penyakit dan gulma. Tinggi tempat dari permukaan laut menentukan suhu udara dan intensitas sinar yang diterima oleh tanaman. Semakin tinggi suatu tempat, semakin rendah suhu tempat tersebut, demikian juga intensitas matahari semakin berkurang. Suhu dan penyinaran inilah yang nantinya akan digunakan untuk menggolongkan tanaman apa yang sesuai untuk dataran tinggi atau dataran rendah. Perubahan suhu tentunya mengakibatkan perbedaan jenis tumbuhan pada wilayah - wilayah tertentu sesuai dengan ketinggian tempatnya (Indriyanto, 2006).

Kerugian yang ditimbulkan gulma terlihat pada penurunan hasil tanaman budidaya. Ketinggian tempat yang berbeda dapat mempengaruhi faktor lingkungan pertumbuhan gulma sehingga menyebabkan perbedaan seperti intensitas cahaya matahari, suhu, kelembaban. Perbedaan ketinggian tempat juga dapat menyebabkan perbedaan vegetasi baik jenis maupun populasi. Mencegah dan memperkecil persaingan antara tanaman dengan gulma dapat diawali dengan mengumpulkan jenis-jenis gulma untuk mengetahui komunitas gulma yang terdapat pada perkebunan kakao sehingga 
diharapkan dapat membantu masyarakat dalam menentukan tindakan pengendalian gulma yang tepat. Berdasarkan hal tersebut perlu dilakukan penelitian untuk mengetahui bagaimana perbandingan komunitas gulma pada perkebunan kakao dataran tinggi dan dataran rendah.

\section{METODE PENELITIAN \\ Waktu dan Tempat}

Penelitian ini dilaksanakan pada bulan Agustus 2016 di dataran tinggi desa DongiDongi (sekitar jalan Palu-Napu) Sulawesi Tengah. Dongi-dongi adalah area dataran tinggi dan sebagian besar termasuk dalam hutan pegunungan, berada pada ketinggian $1.200 \mathrm{~m} \mathrm{dpl}$ di daerah hulu aliran Sungai Sopu - Gumbasa (Dephut, 2015), dan di dataran rendah Desa Sidera dengan ketinggian 81 meter dpl.

\section{Alat dan Bahan}

Alat yang digunakan pada penelitian ini adalah alat tulis menulis, GPS (Global Posititioning System), lux meter, thermohygrometer, meteran, gunting stek, karung, kamera dan parang.

Bahan yang digunakan pada penelitian ini diantaranya spritus, tali raffia, plastik sampah bening atau nener, koran, dan label gantung.

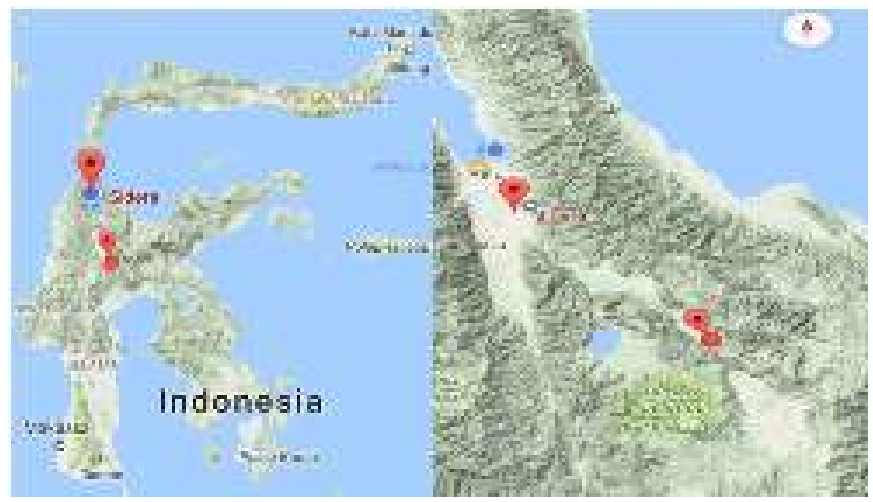

Gambar 1. Peta lokasi penelitian

\section{Prosedur Penelitian}

\section{a. Pengambilan Sampel}

Penelitian ini dilakukan dengan metode jelajah yaitu mendapatkan informasi maupun data-data dengan cara melakukan pengamatan dan pengambilan sampel secara langsung di lokasi penelitian dengan cara pembuatan plot petak ganda yang diletakkan secara purposive sampling yaitu peletakan plot yang dilakuan dengan sengaja untuk mengambil sampel yang telah sesuai dengan semua persyaratan yang akan diperlukan, plot diletakan dilokasi yang dianggap paling mewakili dan cocok untuk dijadikan sebagai tempat pengambilan sampel. Plot tunggal berukuran $50 \times 50 \mathrm{~m}$ dan terdapat sub plot $2 \times 2 \mathrm{~m}$ yang diletakan secara sistemastis, masing - masing satu plot utama $50 \times 50 \mathrm{~m}$ pada dataran tinggi yang di dalamnya terdapat sub plot $2 \times 2$ 
m sebanyak 25 buah, begitupun pada agroforest kakao dataran rendah.

Pada masing-masing sub plot $2 \mathrm{x}$ $2 \mathrm{~m}$ seluruh jenis gulma dilakukan pencatatan jenis dan jumlah spesiesnya. Seluruh morphospesies yang dapat dikenali dicatat nama spesiesnya, sedangkan yang tidak dikenali dilapangan dilakukan pengoleksian spesimen untuk keperluan identifikasi. Kemudian sampel tumbuhan yang telah diambil diberi label gantung yang berisi informasi penting, seperti nama kolektor (inisial), nomor koleksi, tanggal koleksi, karakteristik habitat, ketinggian dan lokasi. Sampel tersebut dimasukan satu per satu ke dalam koran bekas, kemudian disusun dan diikat dengan cukup kuat agar sampel tidak bergesek. Setelah itu, sampel yang telah disatukan kemudian dimasukkan kedalam kantong plastik dan diberi spritus.

\section{b. Pengukuran Faktor Lingkungan}

Pengukuran data lingkungan meliputi suhu udara, kelembaban udara dan intensitas cahaya dilakukan selama 3 kali dalam 1 hari yaitu pada pagi hari (pada pukul 06.00 WITA), pada siang hari (pada pukul 12.00 WITA) dan pada sore hari (pada pukul 18.00 WITA), sedangkan curah hujan tahun 2016 berdasarkan data iklim Badan Meteorologi Klimatologi dan Geofisika
Mutiara Palu. Sedangkan untuk titik koordinat dan ketinggian hanya dilakukan satu kali pengukuran yaitu pada tiap lokasi penelitian yaitu dataran tinggi dan dataran rendah. Untuk data curah hujan diperoleh dari BMKG.

\section{Analisa Data}

Pengukuran besaran Kerapatan Relatif (KR), Frekuensi Relatif (FR) dan Indeks Nilai Penting (INP) dapat dihitung dan dianalisis mengikuti rumus DumboisMuller dan Ellenberg sebagai berikut :

- Kerapatan (K): Jumlah individu

- Kerapatan Relatif (KR):

$$
\frac{\text { Kerapatan suatu Jenis }}{\text { Kerapatan total semua jenis }} \times 100 \%
$$

- Frekuensi(F):

$$
\frac{\text { Jumlah petak ditempat individu }}{\text { Luas total petak }}
$$

- Frekuensi Relatif (FR):

$$
\frac{\text { Frekuensi suatu jenis }}{\text { Frekuensi total semua jenis }} \times 100 \%
$$

Indek Nilai Peting (INP) atau Importance Value Index

$(I V I)=\mathrm{KR}+\mathrm{FR}$

Tinggi atau rendahnya tingkat keanekaragaman jenis vegetasi akan ditentukan menggunakan rumus ShannonWhiener index $\left(\mathrm{H}^{\prime}\right)$ yaitu sebagai berikut :

$$
H^{\prime}=\sum[n i / N] \ln [n i / N]
$$

Keterangan :

$$
H^{\prime}=\text { Indeks keanekaragaman jenis }
$$


$\mathrm{n}=$ Indeks Nilai penting dari suatu jenis I

$\mathrm{N}=$ jumlah total nilai Indeks Nilai Penting

Tabel. 1 Klasifikasi nilai indeks keanekaragaman

\begin{tabular}{clr}
\hline $\begin{array}{c}\text { Nilai } \\
\text { Indeks } \\
\text { Shannon }\end{array}$ & \multicolumn{3}{c}{ Kategori } \\
\hline$>3$ & $\begin{array}{l}\text { Keanekaragaman } \\
\text { penyebaran individu tiap species } \\
\text { tinggi dan kestabilan komunitas } \\
\text { tinggi }\end{array}$ & $\begin{array}{r}\text { tinggi, } \\
\text { keanekaragaman }\end{array}$ \\
\hline $1-3$ & $\begin{array}{l}\text { sedang, } \\
\text { penyebaran jumlah individu tiap } \\
\text { species sedang dan kestabilan } \\
\text { komunitas sedang }\end{array}$ \\
\hline$<1$ & $\begin{array}{l}\text { Keanekaragaman } \\
\text { penyebaran jumlah individu tiap } \\
\text { species rendah dan kestabilan } \\
\text { komunitas rendah }\end{array}$ \\
\hline
\end{tabular}

Kesamaan komunitas diketahui dengan membandingkan setiap dua perkebunan kakao pada tempat tumbuh yang bersamaan digunakan rumus koefisien Indeks of Similarity (IS) atau kesamaan komunitas (C). Nilai IS tertinggi 100\% dan terendah $0 \%$, semakin mendekati 100\% komunitas tumbuhan yang dibandingkan semakin identik.

$$
C=\frac{2 w}{a+b} 100 \%
$$

Dimana :

$$
\begin{array}{llr}
\mathrm{C}(=\mathrm{IS})= & \begin{array}{l}
\text { Koefisien masyarakat atau } \\
\text { Koefisien kesamaan komunitas }
\end{array} \\
\mathrm{W}= & \begin{array}{l}
\text { Jumlah jenis yang sama dari } \\
\text { jenis-jenis yang terdapat dalam }
\end{array} \\
& \text { dua tegakan yang } \\
& \text { dibandingkan } \\
\mathrm{a}= & \begin{array}{l}
\text { Jumlah jenis yang terdapat } \\
\text { pada dataran tinggi }
\end{array} \\
\mathrm{b}= & \begin{array}{l}
\text { Jumlah jenis yang terdapat } \\
\text { pada dataran rendah }
\end{array}
\end{array}
$$

HASIL

\begin{tabular}{|c|c|c|c|}
\hline No. & Famili & Genus & Spesies \\
\hline 1. & Asteraceae & $\begin{array}{l}\text { Ageratum } \\
\text { Bidens } \\
\text { Crassocephalum } \\
\text { Erigeron } \\
\text { Acmella } \\
\text { Synedrella } \\
\text { Galinsoga }\end{array}$ & $\begin{array}{l}\text { Ageratum conyzoides L. } \\
\text { Bidens pillosa L. } \\
\text { Crassocephalum crepediodes (Benth.) } \\
\text { S.Moore } 1912 \\
\text { Erigeron sumatrensis Retz. } \\
\text { Acmella paniculata (Wall. ex DC) } \\
\text { R.K.Jansen } \\
\text { Synedrella nodiflora (L.) } \\
\text { Galinsoga parviflora Cav. }\end{array}$ \\
\hline 2. & Poaceae & $\begin{array}{l}\text { Imperata } \\
\text { Digitaria } \\
\text { Eragrotis } \\
\text { Pasphalum }\end{array}$ & $\begin{array}{l}\text { Imperata cilindrica (L.) Raeusch } \\
\text { Digitaria violascens Link. } \\
\text { Digitaria longiflora (Retz.) Pers. } \\
\text { Eragrotis tenella P. Beauv. } \\
\text { Pasphalum conjugatum P.J. Bergius }\end{array}$ \\
\hline 3. & Lythraceae & Cupea & Cupea balsamona Cham. \& Schltdl. \\
\hline
\end{tabular}

Berdasarkan hasil penelitian, ditemukan 15 famili, 25 Marga dan 26 Spesies di dataran tinggi dan dataran rendah ditemukan 9 Famili, 15 marga dan spesies.

Hasil analisis data Indeks Nilai Penting (INP) dan Keanekaragaman Jenis gulma pada perkebunan kakao di dataran tinggi Desa Dongi-Dongi disajikan pada Tabel 2.

Tabel 2. Jumlah Famili, Genus, Spesies pada Perkebunan Kakao Dataran Tinggi 


\begin{tabular}{clll}
\hline 4. & Cyperaceae & Fimbristylis & Fimbristylis tomentosa Vahl. \\
\hline 5. & Euphorbiaceae & $\begin{array}{l}\text { Euphorbia } \\
\text { Commelina }\end{array}$ & $\begin{array}{l}\text { Euphorbia hirta L. } \\
\text { Commelina difusa Burm. F. }\end{array}$ \\
\hline 6. & Caryophyllaceae & Drymaria & Drymaria cordata (L.) Willd. \\
\hline 7. & Polygonaceae & Poligonum & Poligonum sinensis L. \\
\hline 8. & Verbenaceae & Lantana & Lantana camara L. \\
\hline 9. & Lamiaceae & Hyptis & Hyptis capitata Jacq. \\
\hline 10. & Araceae & Caladium & Caladium sp. \\
\hline 11. & Dryopteridaceae & Nephrolepis & Nephrolepis bisserata (Sw.) Schott. \\
\hline 12. & Rosaceae & Rubus & Rubus fructosus L. \\
\hline 13. & Rubiaceae & Spermacoce & Spermacoce latifolia Aubl. \\
\hline 14. & Convolvulaceae & Ipomea & Ipomea batatas L. \\
\hline 15. & Thelypteridaceae & Sphaerostephanus & Sphaerostephanus sp. \\
\hline
\end{tabular}

Tabel 2. Jumlah Spesies, Genus dan Famili pada perkebunan kakao dataran rendah

\begin{tabular}{|c|c|c|c|}
\hline No. & Famili & Genus & Spesies \\
\hline 1. & Euphorbiaceae & $\begin{array}{l}\text { Euphorbia } \\
\text { Croton } \\
\text { Croton } \\
\text { Jathropa }\end{array}$ & $\begin{array}{l}\text { Euphorbia hirta L. } \\
\text { Croton bonplandianus Baill. } \\
\text { Croton hirtus L'Hèr } \\
\text { Jathropa gossypifolia L. }\end{array}$ \\
\hline 2. & Convovulaceae & $\begin{array}{l}\text { Ipomoea } \\
\text { Ipomoea }\end{array}$ & $\begin{array}{l}\text { Ipomoea pestigridis L. } \\
\text { Ipomoea triloba L. }\end{array}$ \\
\hline 3. & Poaceae & $\begin{array}{l}\text { Dactyloctenium } \\
\text { Chloris }\end{array}$ & $\begin{array}{l}\text { Dactyloctenium aegyptyum L. (Richt) } \\
\text { Chloris barbata Swartz. }\end{array}$ \\
\hline 4. & Cleomaceae & Cleoma & Cleoma rutidosperma D.C \\
\hline 5. & Amaranthaceae & $\begin{array}{l}\text { Amaranthus } \\
\text { Alternantera }\end{array}$ & $\begin{array}{l}\text { Amaranthus spinosus } \mathrm{L} \text {. } \\
\text { Alternantera sessilis } \mathrm{R} . \mathrm{Br} \text {. }\end{array}$ \\
\hline 6. & Phyllanthaceae & Phyllanthus & Phyllanthus urinaria L. \\
\hline 7. & Asteraceae & Acanthospermum & Acanthospermum hispidium DC. \\
\hline 8. & Fabaceae & Macroptilium & Macroptilium atropurpereum (DC.) Urb. \\
\hline 9. & Araceae & Alocasia & Alocasia macoriza Schott. \\
\hline
\end{tabular}

Tabel 3. Indeks Nilai Penting (INP) dan Indeks Keanekaragaman jenis (H') Komunitas gulma pada agroforest kakao di dataran tinggi Desa Dongi-Dongi

\begin{tabular}{lllccccc}
\hline No. & \multicolumn{1}{c}{ Nama Spesies } & Famili & $\Sigma$ & $\begin{array}{c}\text { KR } \\
(\%)\end{array}$ & $\begin{array}{c}\text { FR } \\
(\%)\end{array}$ & $\begin{array}{c}\text { INP } \\
(\%)\end{array}$ & Pi In Pi \\
\hline 1. & Ageratum conyzoides L. & Asteraceae & 935 & $\begin{array}{c}44,2 \\
1\end{array}$ & 17,9 & $\begin{array}{c}62,0 \\
7\end{array}$ & 0,36 \\
\hline 2. & Bidens pillosa L. & Asteraceae & 692 & $\begin{array}{c}32.7 \\
2\end{array}$ & $\begin{array}{c}16,4 \\
5\end{array}$ & $\begin{array}{c}49.1 \\
5\end{array}$ & 0,34 \\
\hline 3. & Imperata cilindrica (L.) Raeusch & Poaceae & 138 & 6.52 & 13 & $\begin{array}{c}15,8 \\
1\end{array}$ & 0,20 \\
\hline 4. & $\begin{array}{l}\text { Crassocephalum crepediodes } \\
\text { (Benth.) S.Moore 1912 }\end{array}$ & Asteraceae & 113 & 5.34 & 10 & $\begin{array}{c}15.3 \\
4\end{array}$ & 0,20 \\
\hline 5. & Erigeron sumatrensis Retz. & Asteracea & 25 & 1.18 & 5 & 6.18 & 0.11 \\
\hline
\end{tabular}


Istikana, dkk. Biocelebes. Desember. 2019. Volume 13 Nomor 3, Halaman 203-217

\begin{tabular}{|c|c|c|c|c|c|c|c|}
\hline 6. & Cupea balsamona Cham. \& Schltdl. & Lythraceae & 24 & 1.13 & 4,29 & 5.42 & 0,10 \\
\hline 7. & Digitaria violascens Link. & Poaceae & 17 & 0.80 & 3,57 & 4,38 & 0,08 \\
\hline 8. & Fimbristylis tomentasa Vahl. & Cyperaceae & 15 & 0.71 & 3,57 & 4,28 & 008 \\
\hline 9. & $\begin{array}{l}\text { Acmella paniculata (Wall. ex DC) } \\
\text { R.K.Jansen }\end{array}$ & Asteraceae & 14 & 0.66 & 3,57 & 4,23 & 0.08 \\
\hline 10. & Synedrella nodiflora (L.) & Asteraceae & 21 & 0,99 & 2,86 & 3,85 & 0,08 \\
\hline 11. & Euphorbia hirta L. & Euphorbiaceae & 18 & 0.85 & 2,86 & 3.71 & 0.07 \\
\hline 12. & $\begin{array}{l}\text { Drymaria cordata (L.) Willd. ex } \\
\text { Schult. }\end{array}$ & Caryophyllaceae & 20 & 0,95 & 2,14 & 3,09 & 0,06 \\
\hline 13. & Digitaria longiflora (Retz.) Pers. & Poaceae & 19 & 0,90 & 2,14 & 3,04 & 0,06 \\
\hline 14. & Poligonum chinense L. & Polygonaceae & 5 & 0.24 & 2,14 & 2.38 & 0.05 \\
\hline 15. & Lantana camara L. & Verbenacea & 4 & 0.19 & 2,14 & 2.33 & 0.05 \\
\hline 16. & Galinsoga parviflora Cav. & Asteraceae & 13 & 0,61 & 1,43 & 2,04 & 0,05 \\
\hline 17. & Hyptis capitata Jacq. & Lamiaceae & 12 & 0.57 & 1,43 & 2.00 & 0.05 \\
\hline 18. & Caladium sp. & Araceae & 9 & 0,43 & 1,43 & 1,85 & 0,04 \\
\hline 19. & Nephrolepis bisserata (Sw.) Schott. & Dryopteridaceae & 8 & 0,38 & 1,43 & 1,81 & 0,04 \\
\hline 20. & Eragrotis tenella P. Beauv. & Poaceae & 3 & 0.14 & 1,43 & 1.57 & 0.04 \\
\hline 21. & Commelina difusa Burm. F. & Euphorbiaceae & 2 & 0.09 & 1,43 & 1,52 & 0,04 \\
\hline 22. & Pasphalum conjugatum P.J. Bergius & Poaceae & 3 & 0,14 & 0,71 & 0,86 & 0,02 \\
\hline 23. & Rubus fruticosus $\mathrm{L}$. & Rosaceae & 2 & 0,09 & 0,71 & 0,81 & 0,02 \\
\hline 24. & Spermacoce latifolia Aubl. & Rubiaceae & 1 & 0,05 & 0,71 & 0,76 & 0,02 \\
\hline 25. & Ipomea batatas L. & Convolvolaceae & 1 & 0,05 & 0,71 & 0,76 & 0,02 \\
\hline \multirow[t]{3}{*}{26.} & Sphaerostephanos sp. & Thelypteridaceae & 1 & 0,05 & 0,71 & 0,76 & 0,02 \\
\hline & Jumlah & & 2115 & $\begin{array}{c}100 . \\
0\end{array}$ & 100 & 200 & \\
\hline & $\mathrm{H}^{\prime}=$ Shanon Diversity Index & & & & & & 2.30 \\
\hline
\end{tabular}

Berdasarkan data pada Tabel 2 diatas, jenis gulma dengan INP tertinggi yaitu tumbuhan Ageratum conyzoides (Asteraceae) dengan jumlah 62,07\%, kemudian di ikuti oleh tumbuhan Bidens pillosa (Asteraceae) dengan jumlah INP $49,15 \%$ dan tumbuhan Imperata cilindrica (Poaceae) dengan INP 15,81 \%, sedangkan gulma dengan INP terendah yaitu tumbuhan Spermacoce latifolia (Rubiaceae), Ipomoea 
batatas

(Convolvolaceae)

Sphaerostephanos

(Thelypteridaceae)

dengan jumlah INP 0,76 \%, sehingga dapat diketahui bahwa indeks keanekaragaman gulma pada dataran tinggi desa Dongi-

Dongi adalah sedang.
Hasil analisis Indeks Nilai Penting (INP) dan keanekaragaman jenis gulma pada agroforest kakao di dataran rendah Desa Sidera adalah sebagai berikut :

Tabel 4. Indeks Nilai Penting (INP) dan Indeks Keanekaragaman jenis ( $\mathrm{H}^{\prime}$ ) Komunitas gulma pada agroforest kakao di dataran rendah Desa Sidera

\begin{tabular}{|c|c|c|c|c|c|c|c|}
\hline No & Nama Spesies & Famili & $\Sigma$ & $\begin{array}{l}\mathrm{KR} \\
(\%)\end{array}$ & $\begin{array}{l}\text { FR } \\
(\%)\end{array}$ & $\begin{array}{l}\text { INP } \\
(\%)\end{array}$ & $\mathrm{Pi} \ln \mathrm{Pi}$ \\
\hline 1 & Euphorbia hirta L. & Euphorbiaceae & 116 & 13,93 & 12,63 & 26,56 & 0,27 \\
\hline 2 & Ipomoea pestigridis L. & Convolvulaceae & 103 & 12,36 & 10,53 & 22,89 & 0,25 \\
\hline 3 & $\begin{array}{l}\text { Dactyloctenium aegyptyum L. } \\
\text { (Richt) }\end{array}$ & Poaceae & 92 & 11,04 & 10,53 & 21,57 & 0,24 \\
\hline 4 & Cleoma rutidosperma D.C & Cleomaceae & 94 & 11,28 & 9,47 & 20,76 & 0,24 \\
\hline 5. & Croton bonplandianus Baill. & Euphorbiaceae & 86 & 10,32 & 9,47 & 19,80 & 0,23 \\
\hline 6. & Croton hirtus L’Hèr & Euphorbiaceae & 84 & 10,08 & 9,47 & 19,56 & 0,23 \\
\hline 7. & Chloris barbata Swartz. & Poaceae & 63 & 7,56 & 7,36 & 14,93 & 0,19 \\
\hline 8. & Amaranthus spinosus L. & Amaranthaceae & 53 & 6,36 & 6,31 & 12,68 & 0,17 \\
\hline 9. & Jathropa gossypifolia L. & Euphorbiaceae & 29 & 3,48 & 5,26 & 8,74 & 0,14 \\
\hline 10. & Ipomoea triloba L. & Convolculaceae & 26 & 3,12 & 5,26 & 8,38 & 0,13 \\
\hline 11. & Alternantera sessilis R.Br. & Amaranthaceae & 22 & 2,64 & 4,21 & 6,82 & 0,12 \\
\hline 12. & Phyllanthus urinaria L. & Phyllanthaceae & 21 & 2,52 & 3,15 & 5,68 & 0,10 \\
\hline 13. & Acanthospermum hispidium DC. & Asteraceae & 20 & 2,40 & 2,10 & 4,51 & 0,09 \\
\hline 14. & $\begin{array}{l}\text { Macroptilium atropurpereum (DC.) } \\
\text { Urb. }\end{array}$ & Fabaceae & 17 & 2,04 & 2,10 & 4,15 & 0,08 \\
\hline 15 & Alocasia macoriza Schott. & Araceae & 7 & 0,84 & 2,10 & 2,95 & 0,06 \\
\hline & Jumlah & & 833 & 100,0 & 100 & 200 & \\
\hline \multicolumn{3}{|c|}{$\mathrm{H}^{\prime}=$ Shanon Diversity Index } & & & & & 2,53 \\
\hline
\end{tabular}

Berdasarkan data pada Tabel 4.7, jenis gulma dengan INP tertinggi yaitu tumbuhan Euphorbia hirta (Euphorbiaceae) dengan jumlah 26,56\%, kemudian di ikuti oleh tumbuhan Ipomoea pestigridis (Convolvulaceae) dengan jumlah INP 22,89 
Istikana, dkk. Biocelebes. Desember. 2019. Volume 13 Nomor 3, Halaman 203-217

$\%$ dan tumbuhan Dactyloctenium aegyptyum (Poaceae) dengan INP 21,57 \%, sedangkan gulma dengan INP terendah yaitu tumbuhan Acanthospermum hispidium (Asteracea) 4,51\%, Macroptilium atropurpereum (Fabaceae) 4,15\%, Alocasia macoriza (Araceae) dengan jumlah INP $2,95 \%$, sehingga dapat diketahui bahwa indeks keanekaragaman gulma pada dataran rendah desa Sidera adalah sedang.

Kesamaan komunitas diketahui dengan membandingkan setiap dua perkebunan kakao pada tempat tumbuh yang bersamaan digunakan rumus Sorensen untuk perhitungan koefisien Indeks of Similarity (IS) atau kesamaan komuitas (C).

Hasil analisis data yang diperoleh dalam perhitungan Indeks Kesamaan komunitas/IS (Indeks Similarity) dengan menggunakan rumus menurut Soerianegara dan Indrawan (2005) disajikan pada Tabel 4.8,

Tabel 5. Hasil Analisis Data Indeks Kesamaan komunitas/IS (Indeks Similarity)

\begin{tabular}{|c|c|c|c|c|}
\hline \multirow[b]{2}{*}{ No. } & \multirow[b]{2}{*}{ Nama Spesies } & \multirow[b]{2}{*}{ Famili } & \multicolumn{2}{|c|}{ Jumlah individu } \\
\hline & & & $\begin{array}{c}\text { Dataran } \\
\text { tinggi }\end{array}$ & $\begin{array}{l}\text { Dataran } \\
\text { rendah }\end{array}$ \\
\hline 1. & Ageratum conyzoides $\mathrm{L}$. & Asteraceae & 935 & - \\
\hline 2. & Bidens pillosa L. & Asteraceae & 692 & - \\
\hline 3. & Imperata cilindrica (L.) Raeusch & Poaceae & 138 & - \\
\hline 4. & $\begin{array}{l}\text { Crassocephalum crepediodes (Benth.) } \\
\text { S.Moore } 1912\end{array}$ & Asteraceae & 113 & - \\
\hline 5. & Erigeron sumatrensis Retz. & Asteracea & 25 & - \\
\hline 6. & Cupea balsamona Cham. \& Schltdl. & Lythraceae & 24 & - \\
\hline 7. & Digitaria violascens Link. & Poaceae & 17 & - \\
\hline 8. & Fimbristylis tomentasa Vahl. & Cyperaceae & 15 & - \\
\hline 9. & $\begin{array}{l}\text { Acmella paniculata (Wall. ex DC) } \\
\text { R.K.Jansen }\end{array}$ & Asteraceae & 14 & - \\
\hline 10. & Synedrella nodiflora (L.) & Asteraceae & 21 & - \\
\hline 11. & Euphorbia hirta L. & Euphorbiaceae & 18 & 116 \\
\hline 12. & Drymaria cordata (L.) Willd. ex Schult. & Caryophyllaceae & 20 & - \\
\hline 13. & Digitaria longiflora (Retz.) Pers. & Poaceae & 19 & - \\
\hline 14. & Poligonum chinense L. & Polygonaceae & 5 & - \\
\hline 15. & Lantana camara L. & Verbenacea & 4 & - \\
\hline 16. & Galinsoga parviflora Cav. & Asteraceae & 13 & - \\
\hline 17. & Hyptis capitata Jacq. & Lamiaceae & 12 & - \\
\hline 18. & Caladium sp. & Araceae & 9 & - \\
\hline
\end{tabular}


Istikana, dkk. Biocelebes. Desember. 2019. Volume 13 Nomor 3, Halaman 203-217

\begin{tabular}{|c|c|c|c|}
\hline 19. Nephrolepis bisserata (Sw.) Schott. & Dryopteridaceae & 8 & - \\
\hline 20. Eragrotis tenella P. Beauv. & Poaceae & 3 & - \\
\hline 21. Commelina difusa Burm. F. & Euphorbiaceae & 2 & - \\
\hline 22. Pasphalum conjugatum P.J. Bergius & Poaceae & 3 & - \\
\hline 23. Rubus fruticosus $\mathrm{L}$. & Rosaceae & 2 & - \\
\hline 24. Spermacoce latifolia Aubl. & Rubiaceae & 1 & - \\
\hline 25. Ipomea batatas L. & Convolvolaceae & 1 & - \\
\hline 26. Sphaerostephanos sp. & Thelypteridaceae & 1 & - \\
\hline 27. Ipomoea pestigridis L. & Convolvulaceae & - & 103 \\
\hline 28. Dactyloctenium aegyptyum L. (Richt) & Poaceae & - & 92 \\
\hline 29. Cleoma rutidosperma D.C & Cleomaceae & - & 94 \\
\hline 30. Croton bonplandianus Baill. & Euphorbiaceae & - & 86 \\
\hline 31. Croton hirtus L`Hèr & Euphorbiaceae & - & 84 \\
\hline 32. $\quad$ Chloris barbata Swartz. & Poaceae & - & 63 \\
\hline 33. Amaranthus spinosus L. & Amaranthaceae & - & 53 \\
\hline 34. Jathropa gossypifolia L. & Euphorbiaceae & - & 29 \\
\hline 35. Ipomoea triloba L. & Convolculaceae & - & 26 \\
\hline 37. Alternantera sessilis R.Br. & Amaranthaceae & - & 22 \\
\hline 38. $\quad$ Phyllanthus urinaria $\mathrm{L}$. & Phyllanthaceae & - & 21 \\
\hline 39. Acanthospermum hispidium DC. & Asteraceae & - & 20 \\
\hline 40. Macroptilium atropurpereum (DC.) Urb. & Fabaceae & - & 17 \\
\hline 41. Alocasia macoriza Schott. & Araceae & - & 7 \\
\hline \multicolumn{4}{|c|}{4,87} \\
\hline
\end{tabular}

Berdasarkan pada Tabel 4.8, hanya terdapat satu spesies yang sama yaitu Euphorbia hirta (Euphorbiaceae) dengan jumlah spesies dataran tinggi sebanyak 18 dan pada dataran rendah merupakan spesies terbanyak yaitu 116 spesies dengan Indeks Similarity yaitu 4,87 \%, sehingga kedua komunitas dikatakan tidak mirip karena memiliki nilai IS sangat rendah. Kedua komunitas dapat dikatakan mirip jika nilai kesamaannya lebih dari 50\% (Suin, 2002).

\section{Pembahasan}

Berdasarkan data yang diperoleh dari hasil penelitian dapat diketahui bahwa keanekaragaman jenis gulma pada perkebunan kakao di dataran tinggi desa Dongi-Dongi, berjumlah 26 jenis yang terdiri dari 16 suku/famili. Sedangkan pada perkebunan kakao di dataran rendah hanya terdapat 15 jenis dari 9 suku/family.

Indek nilai penting (INP) digunakan untuk menggambarkan tingkat Dominansi 
Istikana, dkk. Biocelebes. Desember. 2019. Volume 13 Nomor 3, Halaman 203-217

yang diberikan kepada suatu spesies terhadap komunitas, semakin besar nilai INP suatu spesies maka semakin besar tingkat suatu komunitas atau sebaliknya. Adanya spesies yang mendominasi dapat mempengaruhi persaingan antara tumbuhan yang ada, dalam hal ini berkaitan dengan faktor abiotik dan faktor biotik, jika faktor tersebut mendukung maka spesies tersebut lebih unggul dan lebih banyak ditemukan. Dari hasil penelitian yang diperoleh, jenis gulma yang memiliki INP tertinggi pada agroforest kakao dataran tinggi adalah Ageratum conyzoides dengan jumlah spesies 935 jenis, hal ini disebabkan karena gulma ini dapat berkembang biak melalui biji, mempunyai kemampuan beradaptasi dengan lingkungan, misalnya sedikit air sampai tempat basah dan tahan terhadap naungan, kebutuhan akan cahaya, temperatur, air dan ruang tumbuh terpenuhi sesuai dengan kebutuhannya, sehingga gulma ini dapat berkembang cepat (Reader dan Buck, 2000). Ageratum conyzoides merupakan gulma golongan daun lebar yang termasuk dalam famili Asteraceae. Gulma ini banyak ditemui dipinggir jalan, hutan, ladang, dan lahan terbuka. Buahnya mudah tersebar sedangkan bijinya ringan dan mudah terbawa angin, sehingga mudah untuk berkembangbiak (Prasad, 2011).

Gulma yang memiliki INP tertinggi pada dataran rendah adalah Euphorbia hirta (Euphorbiaceae) dengan jumlah spesies
116. Hal ini disebabkan karena tumbuhan ini memiliki kerapatan yang tinggi serta penyebaran yang baik, karena gulma ini ditemukan pada setiap tempat. Hal ini ditunjang juga oleh habitat Euphorbia hirta yang pada umumnya hidup ditempat yang terlindung, di dataran rendah dan tanahnya tidak terlalu kering juga tidak terlalu lembab. Hal ini sesuai dengan Steenis (2005), yang menyatakan bahwa suatu jenis famili mampu beradaptasi dan cocok pada lingkungan ditemukan dalam jumlah yang banyak atau dominan.

Euphorbia hirta dapat hidup pada ketinggian $1 \mathrm{~m}$ sampai $1400 \mathrm{~m}$ dpl dan hidup pada tanah yang tidak terlalu lembab dan biasanya berumput (Heyne, 1987). Euphorbia hirta L. mampu bertahan hidup selama 1 tahun dan berkembang biak melalui biji. Banyak tumbuh liar di kebun, ladang, tepi dan pekarangan rumah (Hariana, 2008).

Jenis tumbuhan herba yang INP nya tergolong rendah pada perkebunan kakao dataran tinggi yaitu Spermacoce latifolia (Rubiaceae), Ipomea batatas (Convolvolaceae), Sphaerostephanos (Telyptheridaceae) karena hanya ditemukan 1 spesies saja. Rendah nya INP tumbuhan ini juga dikarenakan tumbuhan ini hidup pada daerah terbuka yang cenderung panas dan daerah yang lembab sehingga tidak mampu beradaptasi dengan kondisi lingkungan tersebut. 
Istikana, dkk. Biocelebes. Desember. 2019. Volume 13 Nomor 3, Halaman 203-217

INP terendah pada perkebunan kakao dataran rendah adalah Alocasia machoriza (Araceae) hanya terdapat 7 spesies. Hal ini juga dikarenakan cahaya matahari yang sampai pada lantai hutan umumnya sedikit sekali. Hal ini disebabkan terhalang oleh lapisan-lapisan tajuk pohon yang ada pada hutan tersebut, sehingga tumbuhan yang tumbuh dekat permukaan tanah kurang mendapat cahaya, sedangkan cahaya matahari bagi tumbuhan merupakan salah satu faktor yang penting dalam proses perkembangan, pertumbuhan dan reproduksi (Gusmaylina, 1983). Habitat tumbuhan ini dapat tumbuh pada kisaran ketinggian 70-2000 m dpl (Suhono, 2010).

Suatu jenis dalam suatu komunitas menentukan atau mengendalikan kehadiran jenis lain disebut jenis dominan atau dapat dikatakan sebagai jenis yang berkuasa. Selanjutnya spesies-spesies yang dominan (yang berkuasa) dalam suatu komunitas tumbuhan akan memiliki indeks nilai penting yang tinggi, sehingga spesies yang paling dominan tentu saja memiliki indeks nilai penting yang paling besar.

Setiap jenis tumbuhan mempunyai suatu kondisi minimum, maksimum dan optimum terhadap faktor lingkungan. Spesies yang mendominasi memiliki kisaran batasan yang lebih luas jika dibandingkan dengan jenis yang lainnya terhadap faktor lingkungan, sehingga kisaran toleransi yang luas pada faktor lingkungan menyebabkan spesies tersebut memiliki sebaran yang luas.

Faktor lingkungan abiotik seperti ketinggian, suhu, intensitas cahaya, matahari, dan kelembaban merupakan penentu keberadaan suatu jenis makhluk hidup, hal ini dikarenakan tumbuhan dan seluruh makhluk hidup memiliki batasan toleransi dan faktor untuk tumbuh dan berkembang dengan baik sehingga dapat memperoleh dan memperbanyak keturunannya untuk memperluas penyebaran dan jauh dari kepunahan.

Berdasarkan data temperatur, diketahui bahwa di dataran rendah memiliki temperatur udara yang lebih tinggi daripada dataran tinggi. Di dataran rendah temperatur udaranya adalah sekitar $25^{\circ} \mathrm{C}$ dan di dataran tinggi temperatur udaranya adalah sekitar $22^{\circ} \mathrm{C}$. kondisi ini sesuai dengan Williams dkk. (1980) menyatakan bahwa ketinggian tempat akan mempengaruhi kondisi tanah dan iklim. Lebih lanjut Rukmana (1997) menyatakan bahwa dataran rendah biasanya memiliki curah hujan rendah (< $1.500 \mathrm{~mm} / \mathrm{th}$ ), tingkat kelembaban rendah (30-40\%) dan suhu udara tinggi $\left(>25^{\circ} \mathrm{C}\right)$. Sedangkan daerah dataran tinggi memiliki curah hujan yang tinggi (> $1.500 \mathrm{~mm} / \mathrm{th}$ ), tingkat kelembaban tinggi (65-70\%) dan suhu udara rendah $\left(<25^{\circ} \mathrm{C}\right)$. Menurut Aldrich (1984) gulma menyerang melalui kompetisi terhadap air, unsur hara dan cahaya. Daya 
Istikana, dkk. Biocelebes. Desember. 2019. Volume 13 Nomor 3, Halaman 203-217

kompetisi gulma tersebut dikarenakan gulma mempunyai sifat yaitu tumbuh denga cepat, mempunyai toleransi yang tinggi terhadap faktor lingkungan, daya berkembang biakannya besar baik secara generatif maupun vegetatif, dan biji sangat mudah disebarkan. Kehadirannya yang merugikan secara perlahan dan pasti perlu dikendalikan secara bijaksana.

Keanekaragaman jenis $\left(H^{\prime}\right)$ merupakan karakteristik tingkatan dalam komunitas berdasarkan organisasi biologisnya, yang dapat digunakan untuk menyatakan struktur komunitasnya. Suatu komunitas dikatakan mempunyai keanekarangaman tinggi jika komunitas tersebut disusun oleh banyak jenis dengan kelimpahan tumbuhan yang berbeda dalam satu kawasan. Berdasarkan hasil analisa data dengan menggunakan rumus Shannon-Whiener indekx $\left(H^{\prime}\right)$, didapatkan nilai Shannon-Whiener index (H') pada perkebunan kakao di dataran tinggi yaitu 2,30 \% (Tabel 4.6) kawasan ini merupakan kategori daerah yang memiliki tingkat keanekaragaman jenis vegetasi yang cenderung sedang, sama halnya pada perkebunan kakao di dataran rendah Indeks Keanekaragaman Jenis ( $\left.H^{\prime}\right)$ yaitu $2,53 \%$ (Tabel 4.7) yang juga memiliki tingkat keanekaragaman yang sedang. Indeks keanekaragaman jenis kedua perkebunan kakao sedang, kemungkinan dikarenakan perkebunan kakao tersebut telah dilakukan pengendalian gulma.
Pengendalian gulma dapat didefinisikan sebagai proses membatasi infestasi gulma sedemikian rupa sehingga tanaman budidaya lebih produktif. Dengan kata lain pengendalian bertujuan hanya menekan populasi gulma sampai tingkat populasi yang tidak merugikan secara ekonomi atau tidak melampaui ambang ekonomi, sehingga sama sekali tidak bertujuan menekan populasi gulma sampai nol. Pengendalian gulma dapat dilakukan dengan berbagai cara. Menurut et al (1991) pada dasarnya ada beberapa cara pengendalian gulma yaitu mekanis, kultur teknis, fisik, biologis, kimia dan terpadu. Pengendalian gulma dengan cara kimia lebih diminati akhir akhir ini, terutama untuk lahan pertanian yang cukup luas. Pengendalian gulma dengan cara kimia yaitu dengan pemberian herbisida dapat mengendalikan gulma sebeleum mengganggu, megendalikan gulma pada deretan lurus tanaman pokok, mencegah kerusakan tanaman pokok, lebih efektif membunuh gulma tanaman tahunan dan semak belukar, dan meningkatkan hasil panen pada tanaman pokok dibandingkan dengan penyiangan biasa (Sukman dan Yakup, 1995).

Komunitas gulma pada perkebunan kakao dataran tinggi dan dataran rendah ditemukan 1 jenis tumbuhan yang sama yaitu Euphorbia hirta dengan jumlah koefisien kesamaan komunitas (IS) sebesar 
4,87 \%. Dari hasil penelitian, dapat diketahui bahwa kedua perkebunan kakao tidak memiliki kesamaan komunitas diduga karena faktor lingkungannya berbeda sehingga jenis gulma yang tumbuh pada kedua perkebunan kakao berbeda, hal ini dapat dilihat pada tabel 4.8 IS (Indeks similarity). Menurut Soerianegara dan Indrawan (2005), Indeks of Similarity (IS) atau kesamaan komunitas (C) digunakan untuk mengetahui kesamaan relatif dari komposisi jenis dan struktur antara dua perkebunan kakao dataran tinggi dan dataran rendah.

\section{KESIMPULAN}

Dari penelitian yang telah dilakukan dapat disimpulkan bahwa perkebunan kakao di dataran tinggi didominasi oleh gulma jenis Ageratum conyzoides yang memiliki INP sebsesar $62,07 \%$ dan pada perkebunan kakao di dataran rendah didominasi oleh Euphorbia hirta yang memiliki INP sebesar 26,56\%. Komunitas gulma pada perkebunan kakao dataran tinggi dan perkebunan kakao dataran rendah ditemukan 1 jenis tumbuhan yang sama yaitu Euphorbia hirta yang memiliki jumlah koefisien kesamaan komunitas (IS) sebesar 4,87\%, yang berarti kedua komunitas gulma pada perkebunan kakao tidak mirip, diduga karena memiliki faktor lingkungan yang berbeda.

\section{DAFTAR PUSTAKA}

Gusmaylina. (1983). Analisa Vegetasi Dasar di Hutan Setia Mulia Ladang Padi Padang. Tesis Sarjana Biologi FMIPA UNAND. Padang.

Hariana, A. (2008). Tumbuhan Obat dan Khasiatnya. Cetakan Kelima. Penebar Swadaya. Jakarta.

Heyne, K. (1987). Tumbuhan Berguna Indonesia II. Jakarta : Badan Litbang Kehutanan.

Indriyanto. (2006). Ekologi Hutan. Jakarta: Penerbit PT Bumi Aksara.

Mahfudz. (2005). Dinamika investasi dan karakter ekofisiologi gulma di daerah penyangga Taman Nasional Lore Lindu [disertasi]. Bogor: Sekolah Pascasarjana Institut Pertanian Bogor.

Rahmat, R. (1997). Usaha Tani Jagung. Penerbit Kansius. Jogjakarta.

Sembodo, D. R. J. (2010). Gulma dan Pengelolaanya. Yogyakarta: Graha IImu.

Soerianegara, I., dan Indrawan, A. (2005). Ekologi Hutan Indonesia. Bogor. Fakultas Kehutanan Institut Pertanian Bogor.

Suhono. (2010). Ensiklopedia Biologi Dunia Tumbuhan 7. Jakarta : PT Lentera Abadi.

Suin, N. M. (2002). Metode Ekologi. Padang : Penerbit Universitas Andalas.

Sukman dan Yakup. (1991). Gulma dan Teknik Pengendaliannya. PT Raja Grafindo Persada. Jakarta. 
Istikana, dkk. Biocelebes. Desember. 2019. Volume 13 Nomor 3, Halaman 203-217

Steenis, V. (2005). Flora Untuk Sekolah di Indonesia, Jakarta. PT Pradya Paramita.

Williams, J. G. K., Kubelik, K. J., Livak, J. A., Rafalski, S. V., Tingey. (1980). DNA Polymorphisms Amplified by Arbitary Primers are Useful as Genetic Markers. Nucleic Acids Res. Res. 18. New York : Publisher. 